\title{
PENERAPAN SOCIAL SKILL TRAINING PADA ANAK USIA SEKOLAH DENGAN KESULITAN MENJALIN PERTEMANAN
}

\author{
Detricia Tedjawidjaja ${ }^{1}$, Ike Anggraika Kuntoro ${ }^{2}$ \\ ${ }^{1,2}$ Fakultas Psikologi, Universitas Indonesia \\ Jl. Margonda Raya, Pondok Cina, Kecamatan Beji, Kota Depok, Jawa Barat 16424 \\ E-mail: detricia.tedjawidjaja@gmail.com
}

\begin{abstract}
ABSTRAK
Salah satu tugas perkembangan yang penting pada saat anak memasuki usia sekolah adalah membangun hubungan yang lebih dekat dengan teman sebaya. Anak yang mengalami kesulitan menjalin hubungan teman sebaya mengarah pada berbagai masalah emosi dan perilaku. Salah satu kunci untuk dapat membangun hubungan teman sebaya yang baik adalah memiliki keterampilan sosial. Defisit dalam keterampilan sosial berdampak negatif terhadap fungsi sosial, emosional, dan akademik anak. Social Skill Training (SST) merupakan intervensi yang mengajarkan keterampilan yang dibutuhkan untuk menjalin interaksi sosial. Tujuan penelitian ini adalah meningkatkan keterampilan sosial pada anak usia sekolah dengan menggunakan SST. Penelitian ini menggunakan single-subject study dengan pre-test dan post-test yang diterapkan pada seorang partisipan berusia 9 tahun 10 bulan yang dikeluhkan mengalami kesulitan membangun hubungan pertemanan di sekolah. Ia menunjukkan defisit dalam tiga komponen keterampilan sosial, yaitu memberikan dan menerima pujian, melakukan percakapan, dan menunjukkan empati. Hasil penelitian menunjukkan bahwa SST terbukti berhasil dalam meningkatkan keterampilan sosial pada ketiga komponen tersebut. Peningkatan keterampilan sosial sejalan dengan kemampuan menjalin hubungan teman sebaya yang lebih dekat dengan teman di sekolah. Pengukuran yang dilakukan tiga minggu setelah intervensi menunjukkan bahwa peningkatan tersebut dapat diterapkan dan digeneralisasikan dalam situasi kehidupan sehari-hari.
\end{abstract}

Kata kunci: social skill training; keterampilan sosial; hubungan teman sebaya; anak usia sekolah

\section{THE IMPLEMENTATION OF SOCIAL SKILL TRAINING FOR SCHOOL-AGED CHILD WITH DIFFICULTY IN ESTABLISHING PEER-RELATIONSHIP}

\begin{abstract}
One of crucial developmental tasks as children move into school-age is to form mutual peer relationship. Children with difficulties in establishing peer relationships lead to several emotional and behavioral problems. One of the keys to build good peer relations is having social skills. Deficits in social skills negatively affect children's social, emotional, and academic functioning. Social Skill Training (SST) as an intervention program that aims to teach necessary skills to establish social interaction. The purpose of this study is to increase social skills in school-age children by using SST. This study uses a single-subject study with pre-test and post-test to a participant aged 9 years and 10 months who is complained about having difficulty in establishing friendship at school. Participant showed deficits in the three components of social skills, specifically giving and receiving compliment, making conversations, and showing empathy. The results indicated that SST is successfully increasing social skills in all three components. The increase of social skills is in line with the ability to establish mutual peer relationships at school. Measurements which was made three weeks after the intervention showed that treatment gains could be applied and generalized in daily life situations.
\end{abstract}

Keywords: social skill training; social skill; peer-relationship; school-age children

\section{PENDAHULUAN}

Hubungan teman sebaya memegang peranan yang penting dalam masa perkembangan, khususnya pada masa kanak-kanak. Ketika memasuki usia sekolah, anak-anak lebih banyak menghabiskan waktu dengan teman sebaya daripada dengan orang dewasa (Rubin, Coplan, Chen, Bowker, \& McDonald, 2011; Shaffer, 2009). Dengan memiliki hubungan teman sebaya, anak mendapat kenyamanan secara emosional dan dukungan sosial (Shaffer, 2009). Anak dapat belajar untuk memecahkan masalah sosial dalam hubungan 
pertemanan. Hubungan yang baik dengan teman sebaya berpengaruh terhadap perkembangan self-esteem (Gruenenfelder-Steiger, Harris, \& Fend, 2016). Hubungan pertemanan juga dapat mendukung proses penyesuaian diri anak secara positif (Bukowski, Motzoi, \& Meyer, 2009; Rubin et al., 2011). Dalam bidang akademik, penerimaan teman sebaya merupakan sumber daya bagi anak untuk memiliki pencapaian akademik yang tinggi (Chen, Rubin, \& Li, 1997).

Memiliki hubungan teman sebaya yang harmonis semakin dinilai berharga dan penting dalam budaya kolektif dibandingkan dengan budaya individualistik (Malikiosi-Loizos \& Anderson, 1999). Anak diharapkan dan didorong untuk mampu menjadi bagian dalam kelompok dengan mempertahankan hubungan sosial (Sharabany, 2006 dalam Fandrem, 2015). Dalam budaya kolektif, teman sebaya dinilai penting karena berfungsi sebagai bantuan dan pendampingan bagi orang lain (Fandrem, 2015).

Penelitian menunjukkan bahwa mereka yang tidak memiliki teman atau ditolak dalam hubungan teman sebaya memiliki risiko lebih besar untuk mengalami masalah kesehatan mental (Rubin et al., 2011). Anak yang mendapat penolakan dari teman sebaya cenderung menghindari sekolah, memiliki pencapaian akademik yang rendah, kurang berpartisipasi di kelas, dan lebih merasa kesepian (Buhs \& Ladd, 2001). Selanjutnya, berbagai penelitian menunjukkan bahwa penolakan dari teman dapat memprediksi terjadinya masalah internalisasi, seperti kecemasan, depresi, dan kesepian (Prinstein, Rancourt, Guerry, \& Browne, 2009; TroopGordon, MacDonald, \& Corbitt-Hall, 2019). Dengan demikian, hubungan teman sebaya berkontribusi penting bagi anak, tetapi tidak semua anak dapat membangun hubungan pertemanan dengan sukses. Parker \& Asher (dalam Rubin et al., 2011) menunjukkan bahwa $15-20 \%$ anak dan remaja awal tidak memiliki hubungan pertemanan yang dekat.

Salah satu kunci untuk dapat membangun hubungan teman sebaya yang baik adalah memiliki keterampilan sosial (Bagwell, 2005; Berk, 2013). Keterampilan sosial merupakan kemampuan menerapkan perilaku untuk berinteraksi sosial sesuai dengan konteks situasi sosialnya (Spence, 2003). Rose (1983) menjelaskan terdapat beberapa keterampilan sosial yang perlu dikuasai oleh anak usia sekolah, antara lain keterampilan verbal (kemampuan memulai, mempertahankan, dan menutup percakapan), keterampilan nonverbal (membuat kontak mata, melihat kepada lawan bicara), serta bantuan dan perilaku kooperatif (mau berbagi dan bergiliran dengan anak lain). Kegagalan dalam menunjukkan keterampilan sosial tersebut dikenal dengan social skill deficits (Hupp et al., 2009).

Keterampilan sosial penting untuk mempertahankan dan mengembangkan hubungan teman sebaya yang positif selama masa anak-anak hingga dewasa (Blundon \& Schaefer, 2006; Eisler \& Frederiksen, 1980; LeCroy, 2008). Anak yang populer dalam kelompok teman sebaya mampu menampilkan keterampilan sosial dalam menjalin interaksi yang positif dan berkomunikasi dengan memahami sudut pandang orang lain (Michelson, Sugai, Wood, \& Kazdin, 1983). Di sisi lain, anak yang menunjukkan defisit dalam keterampilan sosial, seperti tidak mampu melakukan negosiasi dan kompromi, cenderung mengalami frustrasi dalam memenuhi tuntutan sosial (Corner, 1988 dalam Whitted, 2011). Defisit pada keterampilan sosial juga mengarah pada pengalaman interpersonal yang tidak menyenangkan, sehingga lebih berisiko untuk mengembangkan gangguan depresi (Segrin, 2000). Defisit dalam keterampilan sosial juga berpengaruh terhadap performa akademik di sekolah (Gustavsen, 2017). Anak cenderung mengalami kesulitan untuk mengikuti instruksi dan kurang terlibat secara positif dalam kegiatan pembelajaran (Konold, Jamison, Stanton-Chapman, \& Rimm-Kaufman, 2010). Dengan demikian, anak yang mengalami defisit dalam keterampilan sosial dapat mengarah pada masalah dalam hubungan teman sebaya yang pada akhirnya berdampak negatif terhadap fungsi sosial, emosional, dan akademik.

Defisit dalam keterampilan sosial ditunjukkan oleh seorang partisipan penelitian (inisial G), perempuan berusia 9 tahun 10 bulan dan sedang duduk di kelas 4 sekolah dasar. Ia dikeluhkan oleh orang tuanya karena cenderung pendiam, hanya memiliki satu teman dekat di luar sekolah, sama sekali tidak memiliki teman dekat di kelas, dan membutuhkan waktu lama untuk dapat memulai interaksi dengan orang lain di dalam lingkungan yang baru. Di samping itu, G menunjukkan beberapa defisit dalam keterampilan sosial, seperti tidak pernah memulai percakapan dengan teman dan memberikan jawaban yang singkat dalam percakapan. G juga menunjukkan ekspresi wajah yang selalu datar dan kurang dapat memahami perasaan orang lain. Berdasarkan defisit dalam keterampilan sosial tersebut, $\mathrm{G}$ membutuhkan intervensi yang spesifik untuk membantu meningkatkan keterampilan sosialnya.

Salah satu intervensi yang dapat meningkatkan keterampilan sosial anak adalah Social Skill Training yang selanjutnya disingkat sebagai SST. SST dikembangkan pertama kali oleh Wolfe dan Lazarus pada tahun 1966 berupa assertion-training (Eisler \& Frederiksen, 1980). Assertion-training menjadi penelitian awal yang berpengaruh penting terhadap perkembangan SST. Sekitar tahun 1980-an, SST mulai berkembang dengan mencakup keterampilan sosial yang defisit (Eisler \& Frederiksen, 1980). Setelah itu, SST mulai berkembang dengan berbagai pendekatan, seperti program Structured Learning yang disusun oleh Goldstein dan kolega yang khusus menangani anak atau remaja dengan masalah kenakalan. Selanjutnya, Schumaker dan kolega mengembangkan ASSET (Adolescent Social Skill Effectiveness Training Program) untuk meningkatkan keterampilan sosial bagi anak-anak yang berurusan dengan pengadilan (Hazel, 
Schumaker, Sherman, \& Sheldon-Wildgen, 1983; LeCroy, 1983b).

Selain Goldstein dan Schumaker, SST juga dikembangkan oleh LeCroy dengan pendekatan terapi kelompok (LeCroy, 1983a; LeCroy \& Rose, 1986). LeCroy mengembangkan SST yang dapat digunakan untuk menangani masalah emosi dan perilaku yang sudah berada dalam ranah gangguan serta meningkatkan keterampilan sosial bagi anak yang kesulitan menjalin hubungan pertemanan (LeCroy, 2008). Penelitian menunjukkan bahwa SST yang disusun oleh LeCroy terbukti memberikan manfaat kepada anak usia sekolah, khususnya dalam meningkatkan kompetensi sosial, anger control skills, hubungan dengan teman sebaya dan orang tua, serta menurunkan tingkat agresi dan conduct problem (LeCroy \& Rose, 1986; Sukhodolsky, Golub, Stone, \& Orban, 2005). SST juga efektif digunakan sebagai upaya preventif kepada remaja yang menggunakan obat-obatan (LeCroy \& Mann, 2004).

Prinsip belajar yang digunakan LeCroy dalam SST adalah social learning theory (LeCroy, 2015). Berdasarkan prinsip tersebut, terdapat beberapa langkah dalam mengajarkan suatu keterampilan sosial, yaitu: (1) menjelaskan tentang keterampilan sosial yang akan diajarkan, (2) berdiskusi mengenai aspek dan langkahlangkah penting pada keterampilan sosial tersebut, (3) memberikan contoh situasi dan modeling mengenai bagaimana cara menerapkannya, (4) behavioral rehearsal berupa role playing, (5) coaching dan memberikan umpan balik, dan (6) berlatih dengan menggunakan situasi yang lebih kompleks (LeCroy \& Rose, 1986; LeCroy, 2008; LeCroy, 2013). Meskipun SST dirancang dalam kegiatan berkelompok, SST tetap dapat diterapkan secara individual. SST yang diberikan secara individual telah diterapkan oleh Bulkeley \& Cramer (1994), dimana hasil penelitiannya adalah, baik SST yang diberikan secara berkelompok maupun individual, sama-sama mampu meningkatkan kompetensi sosial anak. Di samping itu, keterampilan sosial tidak hanya dilatih dalam setting intervensi, tetapi juga diajarkan pada setting sehari-hari melalui pemberian tugas rumah agar partisipan dapat menerapkan keterampilan di luar sesi intervensi (LeCroy, 2015).

Terdapat 11 keterampilan sosial yang dianggap penting oleh LeCroy (2008) dalam membangun interaksi yang positif dengan orang lain, yaitu:

Unit 1 : Creating Positive Interactions

Unit 2 : Getting to Know Others: Starting Conversations

Unit 3 : Making Requests: Getting More of What You Want

Unit 4 : Expressing Your Feelings Directly

Unit 5 : Getting Out: How to Say "No"

Unit 6 : Asserting Your Rights: Tell it Like it Is

Unit 7 : Identifying How Others Feel: The Art of Empathy
Unit 8 : Dealing with Those in Authority: Staying out of Trouble

Unit 9 : Responsible Decision Making: Think about It Unit 10 : Learning to Negotiate: Conflict Resolution Unit 11 : When You are in Need: Asking for Help

LeCroy (2008) menjelaskan bahwa ke-11 unit di atas dapat ditambahkan, dikurangi, atau dimodifikasi berdasarkan kebutuhan yang berbeda-beda pada setiap anak. Penting untuk menentukan keterampilan yang akan diajarkan agar proses intervensi secara khusus menekankan pada keterampilan yang dibutuhkan saja.

Penelitian ini menggunakan SST yang dikembangkan oleh LeCroy dengan beberapa pertimbangan. Pertimbangan pertama adalah program SST LeCroy merupakan intervensi yang dinilai cocok diberikan pada masalah $\mathrm{G}$ yang menunjukkan kesulitan membangun hubungan teman sebaya. Selanjutnya, LeCroy menekankan pada prinsip social learning theory yang dinilai lebih mudah diajarkan kepada $G$ yang berada di usia sekolah. Meskipun demikian, dalam penelitian ini, SST yang diterapkan kepada partisipan bukan menggunakan pendekatan terapi kelompok, tetapi diberikan secara individual. Oleh karena itu, peneliti melibatkan peran teman sebaya dalam intervensi agar partisipan memperoleh kesempatan melatih keterampilan sosialnya dalam hubungan dengan teman sebaya. Mengingat bahwa LeCroy memiliki beberapa komponen keterampilan sosial di dalam intervensinya, peneliti menentukan beberapa keterampilan sosial yang dinilai paling dibutuhkan oleh partisipan.

Tujuan penelitian ini adalah menguji efektivitas SST dalam meningkatkan keterampilan sosial anak usia sekolah dengan kesulitan menjalin pertemanan. Peneliti merumuskan dua hipotesis yang akan diuji dalam penelitian ini, yaitu (1) SST efektif meningkatkan keterampilan sosial pada anak usia sekolah dan (2) peningkatkan pada keterampilan sosial sejalan dengan kemampuan dalam menjalin pertemanan. Penelitian ini penting untuk dilakukan dengan harapan bahwa hasil dari penelitian ini dapat menjadi acuan tentang penerapan SST dalam membantu anak usia sekolah yang memiliki masalah yang serupa dengan masalah $\mathrm{G}$.

\section{METODE}

\section{Partisipan Penelitian}

Partisipan dalam penelitian ini berinisial G, seorang anak perempuan berusia 9 tahun 10 bulan yang duduk di kelas 4 SD. Partisipan melakukan pemeriksaan di Klinik Terpadu Psikologi Universitas Indonesia dengan keluhan bahwa ia tidak memiliki teman dekat di kelas, jarang berbicara dengan orang lain, dan membutuhkan waktu lama untuk berinteraksi sosial dalam lingkungan yang baru. Hasil pemeriksaan psikologis menunjukkan bahwa $\mathrm{G}$ memiliki defisit pada keterampilan sosial yang menghambatnya dalam menjalin hubungan dengan teman sebaya. 
Secara spesifik, G menunjukkan defisit pada beberapa area keterampilan sosial. G hampir tidak pernah menyapa dan menginisiasi percakapan dengan orang lain. Ia cenderung menunggu sampai ada orang lain yang mengajaknya berbicara atau bermain bersama. Ketika ada teman yang mengajak $G$ berbicara, ia cenderung diam dan kurang memberikan respons kepada lawan bicara. Pada saat $\mathrm{G}$ berbicara, ekspresi wajah dan intonasi suaranya cenderung datar. Dalam hubungan pertemanan, meskipun terdapat beberapa anak di kelas yang berusaha mengajak $G$ melakukan kegiatan bersama-sama, $G$ tetap kesulitan untuk membangun hubungan yang lebih dekat dengan anak-anak tersebut. Ia tidak mampu menjalin pertemanan dengan siapapun di kelas.

Berdasarkan defisit pada keterampilan sosial tersebut, G mendapatkan intervensi yang hanya meliputi tiga komponen, yaitu (1) Creating Positive Interactions,

(2) Getting to Know Others: Starting Conversations, dan (3) Identifying How Others Feel: The Art of Empathy.

\section{Desain Penelitian}

Penelitian ini menggunakan single-subject design dengan memberikan pre-test dan post-test kepada satu orang partisipan. Hasil pengukuran pada saat pre-test akan dibandingkan dengan hasil pengukuran pada saat post-test untuk mengetahui apakah SST berhasil meningkatkan keterampilan sosial G. Post-test akan dilaksanakan sebanyak dua kali untuk memastikan apakah SST berhasil meningkatkan keterampilan sosial $\mathrm{G}$ secara berkelanjutan pada kehidupan sehari-hari. Desain dan prosedur secara lebih jelas dapat dilihat pada Gambar 1.

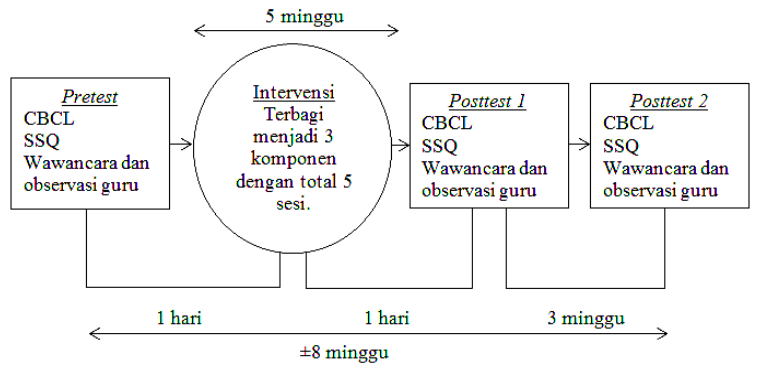

Gambar 1. Desain dan prosedur penelitian

\section{Alat Ukur}

Terdapat dua alat ukur yang digunakan dalam penelitian ini, yaitu Child Behavior Checklist (CBCL/418) yang diisi oleh orang tua dan Social Skill Questionnaire (SSQ) yang diisi oleh guru.

CBCL digunakan untuk mengukur masalah perilaku dan kompetensi pada anak usia 4 sampai dengan 18 tahun (Achenbach, 1991). Orang tua mengisi CBCL hanya pada problem scale, terutama pada ranah withdrawal dan social problem dengan pertimbangan bahwa kedua ranah tersebut yang paling merepresentasikan keterampilan sosial dan hubungan $\mathrm{G}$ dengan teman sebaya. Total item yang akan diisi berjumlah 17 dengan pola jawaban rating 0-2 poin skala Likert $(0=$ tidak pernah, $1=$ kadang-kadang, $2=$ sering). Total nilai yang diperoleh akan diubah menjadi $T$-score dan akan dibandingkan dengan norma anak yang memiliki usia dan jenis kelamin yang sama dengan partisipan untuk mengetahui apakah kedua ranah tersebut berada pada normal range, borderline clinical range, atau clinical range.

SSQ digunakan untuk mengukur keterampilan sosial partisipan (Spence, 1995). Guru akan mengisi SSQ-T (teacher form) yang terdiri dari 30 item. SSQ terbagi menjadi tiga faktor, yaitu resolusi/penghindaran konflik, kehangatan dan empati, serta keterlibatan sosial. Meskipun demikian, sebaiknya skor yang digunakan dalam pengukuran adalah skor keseluruhan. Berdasarkan hasil data normatif dari 313 partisipan berusia 8-17 tahun, rata-rata skor SSQ anak perempuan berusia 8-11 tahun sebesar 56,58 dengan $S D=6,53$ (Spence, 1995).

\section{Prosedur Penelitian}

Prosedur penelitian diawali dengan pre-test, pelaksanaan intervensi, dan terakhir adalah post-test. Pre-test dilaksanakan dengan mengukur keterampilan sosial G sebelum intervensi diberikan. Peneliti meminta orang tua untuk mengisi CBCL dan guru untuk mengisi SSQ. Peneliti juga melakukan wawancara dan meminta guru untuk mengobservasi $\mathrm{G}$ berkaitan dengan ketiga komponen keterampilan sosial yang ingin dicapai. Selain melakukan pengukuran, peneliti juga akan menjelaskan mengenai gambaran intervensi dan peran masing-masing guru dan orang tua dalam proses intervensi. Peneliti meminta persetujuan orang tua, guru, dan $\mathrm{G}$ untuk mengikuti intervensi ini dengan menandatangani informed consent.

Pelaksanaan intervensi terbagi menjadi lima sesi dengan masing-masing durasi sekitar 60 menit. Sesi yang pertama mewakili komponen Creating Positive Interactions yang bertujuan untuk membangun hubungan yang positif dengan teman sebaya dengan memberikan dan menerima pujian. Sesi kedua sampai dengan keempat mewakili komponen Getting to Know Others: Starting Conversations yang digunakan untuk melatih G dalam melakukan percakapan (memulai, mempertahankan, dan menutup percakapan). Sesi kelima mewakili komponen Identifying How Others Feel: The Art of Empathy yang bertujuan untuk melatih $\mathrm{G}$ dalam mengidentifikasi perasaan serta menunjukkan empati kepada orang lain. Susunan setiap sesi terdiri dari 4 tahap, yaitu (1) pengenalan materi, (2) latihan dengan menyelesaikan lembar kerja, (3) modeling dan roleplay bersama peneliti, teman, dan/atau anggota keluarga, dan (4) tugas rumah untuk menerapkan keterampilan sosial dalam keseharian. Deskripsi kegiatan pada setiap sesi secara lebih rinci dapat dilihat pada Tabel 1. 
Tabel 1. Tahap Pelaksanaan Intervensi

\begin{tabular}{|c|c|c|c|}
\hline Komponen & Target Perilaku & Sesi & Kriteria Keberhasilan \\
\hline \multirow[t]{2}{*}{$\begin{array}{l}\text { Creating } \\
\text { Positive } \\
\text { Interactions }\end{array}$} & Memberikan Pujian & 1 & $\begin{array}{l}\text { G mampu menerapkan skill dalam memberikan pujian kepada orang } \\
\text { lain, yaitu menyampaikan hal yang baik kepada orang lain dengan } \\
\text { nonverbal skill yang sesuai. }\end{array}$ \\
\hline & Menerima Pujian & & $\begin{array}{l}\text { G mampu menerapkan skill dalam menerima pujian, yaitu } \\
\text { mengucapkan 'Terima kasih’ dengan nonverbal skill yang sesuai. }\end{array}$ \\
\hline \multirow{3}{*}{$\begin{array}{l}\text { Getting to } \\
\text { Know } \\
\text { Others: } \\
\text { Starting } \\
\text { Conversa- } \\
\text { tions }\end{array}$} & Memulai percakapan & 2 & $\begin{array}{l}\text { G mampu menerapkan skill dalam memulai percakapan, yaitu } \\
\text { menyapa, memperkenalkan diri, atau bertanya dengan nonverbal skill } \\
\text { yang sesuai terutama kepada teman yang baru ia kenal. }\end{array}$ \\
\hline & $\begin{array}{l}\text { Mempertahankan } \\
\text { percakapan }\end{array}$ & 3 & $\begin{array}{l}\text { G mampu menerapkan skill dalam mempertahankan percakapan, } \\
\text { yaitu memberikan pertanyaan terbuka atau pernyataan. }\end{array}$ \\
\hline & Menutup percakapan & 4 & $\begin{array}{l}\text { G mampu menerapkan skill dalam menutup percakapan, yaitu } \\
\text { mengundurkan diri dan merencanakan pertemuan berikutnya. }\end{array}$ \\
\hline \multirow[t]{2}{*}{$\begin{array}{l}\text { Identifying } \\
\text { How Others } \\
\text { Feel: The } \\
\text { Art of } \\
\text { Empathy }\end{array}$} & $\begin{array}{l}\text { Memahami jenis-jenis } \\
\text { emosi dan situasi yang } \\
\text { melatar-belakangi } \\
\text { emosi tersebut }\end{array}$ & 5 & $\begin{array}{l}\text { G mampu mengidentifikasi } 10 \text { jenis emosi dan situasi yang } \\
\text { melatarbelakangi emosi tersebut muncul. }\end{array}$ \\
\hline & Menunjukkan empati & & $\begin{array}{l}\text { G mampu menerapkan skill dalam menunjukkan empati, yaitu } \\
\text { memberikan pernyataan empati dengan nonverbal skill yang sesuai. }\end{array}$ \\
\hline
\end{tabular}

Selain melaksanakan kegiatan dalam setiap sesi, peneliti juga akan menerapkan sistem reinforcement berupa token economy. Peneliti akan menilai hasil pengerjaan latihan selama sesi, pengerjaan tugas rumah, dan hasil observasi oleh guru atau teman pada masingmasing komponen keterampilan sosial untuk ditukarkan dengan token berupa stiker. Stiker yang terkumpul akan ditukarkan dengan back-up reinforcers berupa uang tabungan yang sudah disepakati oleh orang tua dan partisipan.

Post-test dilaksanakan sebanyak dua kali. Post-test 1 dilaksanakan satu hari setelah sesi kelima untuk mengetahui perubahan keterampilan sosial $\mathrm{G}$ setelah intervensi diberikan. Kemudian, post-test 2 dilaksanakan tiga minggu setelah intervensi selesai untuk mengukur apakah peningkatan keterampilan sosial yang $G$ tunjukkan masih dapat bertahan dalam lingkungan sehari-hari.

\section{Analisis Data}

Tujuan dari desain penelitian single-subject adalah untuk menentukan apakah manipulasi pada satu variabel, yang dalam hal ini adalah pemberian intervensi SST, dapat menyebabkan perubahan pada variabel yang lain, dalam hal ini adalah keterampilan sosial G (Gravetter \& Forzano, 2009). Berdasarkan hal tersebut, analisis data dilakukan dengan membandingkan hasil CBCL dan SSQ antara pre-test, post-test 1, dan post-test 2 untuk mengetahui apakah terdapat peningkatan pada keterampilan sosial G. Perbandingan hasil pengukuran antara pre-test, post-test 1 , dan post-test 2 akan disajikan secara visual menggunakan grafik. Di samping itu, data yang diperoleh melalui wawancara dan observasi guru akan dianalisis secara kualitatif.

\section{HASIL DAN PEMBAHASAN}

Intervensi Social Skill Training (SST) ini diberikan dengan tujuan untuk meningkatkan keterampilan sosial G. Berikut ini adalah hasil intervensi yang terbagi berdasarkan capaian target perilaku dalam intervensi, laporan orang tua, dan laporan dari guru. Hasil dari intervensi berdasarkan capaian target perilaku diperoleh dari pengamatan peneliti selama sesi intervensi berlangsung.

\section{Hasil intervensi berdasarkan capaian target perilaku}

Dalam menentukan apakah tujuan intervensi ini sudah tercapai, peneliti membandingkan setiap komponen keterampilan sosial antara sebelum dan sesudah intervensi. Terdapat tiga komponen yang menjadi tujuan dari intervensi ini, yaitu Creating Positive Interactions, Getting to Know Others: Starting Conversations, dan Identifying How Others Feel: The Art of Empathy. Ketiga komponen tersebut terbagi menjadi tujuh target perilaku, yaitu (1) memberikan pujian, (2) menerima pujian, (3) memulai percakapan, (4) mempertahankan percakapan, (5) menutup percakapan, (6) memahami jenis-jenis emosi dan situasi yang melatarbelakangi emosi tersebut, dan (7) menunjukkan empati.

Pada komponen Creating Positive Interactions, target perilaku yang harus dicapai adalah memberikan dan menerima pujian. G cukup mampu menguasai dua target perilaku tersebut. Peningkatan keterampilan sosial pada komponen ini dapat terlihat dari kemampuan $G$ memberikan pujian yang lebih bervariasi sesuai dengan situasinya dan menerima pujian dengan bangga, bukan 
sombong ataupun rendah diri. Perubahan keterampilan secara spesifik dapat dilihat pada Tabel 2.

Tabel 2. Perubahan Komponen Creating Positive Interactions

\begin{tabular}{|c|c|}
\hline $\begin{array}{l}\text { Keterampilan sosial } \\
\text { sebelum intervensi }\end{array}$ & $\begin{array}{l}\text { Keterampilan sosial setelah } \\
\text { intervensi }\end{array}$ \\
\hline \multicolumn{2}{|l|}{ Memberikan pujian } \\
\hline VERBAL & VERBAL \\
\hline $\begin{array}{l}\text { - G memberikan pujian } \\
\text { hanya berupa "Hebat" } \\
\text { atau "Bagus". }\end{array}$ & $\begin{array}{l}\text { - G menambahkan variasi } \\
\text { pujiannya, seperti "Seru" } \\
\text { dan "Cantik". }\end{array}$ \\
\hline NONVERBAL & NONVERBAL \\
\hline $\begin{array}{l}\text { - Ekspresi wajah G datar, } \\
\text { ragu-ragu, dan tampak } \\
\text { berpikir terlebih dahulu. }\end{array}$ & $\begin{array}{l}\text { - G memberikan pujian } \\
\text { dengan lebih percaya diri } \\
\text { dan spontan. }\end{array}$ \\
\hline \multicolumn{2}{|l|}{ Menerima pujian } \\
\hline $\begin{array}{l}\text { VERBAL: } \\
\text { - G hanya mampu } \\
\text { mengatakan terima kasih. }\end{array}$ & $\begin{array}{l}\text { VERBAL: } \\
\text { - G mampu mengatakan } \\
\text { terima kasih dan } \\
\text { mengelaborasinya. }\end{array}$ \\
\hline $\begin{array}{l}\text { NONVERBAL: } \\
\text { - G tidak melihat ke arah } \\
\text { orang yang memberi } \\
\text { pujian. }\end{array}$ & $\begin{array}{l}\text { NONVERBAL: } \\
\text { - G menunjukkan senyum } \\
\text { ketika ia menerima } \\
\text { pujian. }\end{array}$ \\
\hline
\end{tabular}

Pada komponen Getting to Know Others: Starting Conversations, target perilaku yang harus dicapai adalah memulai, mempertahankan, dan menutup percakapan. Setelah diberikan intervensi, G lebih mudah menguasai kemampuan mempertahankan dan menutup percakapan dibandingkan dengan kemampuan memulai percakapan. G masih kesulitan menerapkan cara-cara memulai percakapan dengan membuat pertanyaan lebih dahulu, dan cenderung menunjukkan nonverbal skill yang tidak sesuai, seperti malu dan tergesa-gesa. Dalam mempertahankan dan menutup percakapan, $G$ sudah mampu memberikan jawaban lebih panjang, mengajukan pertanyaan, dan mengundurkan diri dari percakapan. Perubahan keterampilan secara spesifik dapat dilihat pada Tabel 3 .

Tabel 3. Perubahan Komponen Getting to Know Others: Starting Conversations

\begin{tabular}{ll}
\hline $\begin{array}{l}\text { Keterampilan sosial } \\
\text { sebelum intervensi }\end{array}$ & $\begin{array}{l}\text { Keterampilan sosial setelah } \\
\text { intervensi }\end{array}$ \\
\hline \multicolumn{1}{c}{ Memulai percakapan } & \\
\hline VERBAL & VERBAL \\
- G memulai percakapan & $\bullet$ G membutuhkan waktu \\
dengan mengajak orang & berpikir sekitar 5-10 \\
lain bermain. & petik untuk mengajukan \\
NONVERBAL & NONtanyaan. \\
- G hanya diam saja ketika & - G menyampaikan \\
ia bertemu orang yang & pertanyaan dengan \\
baru ia kenal. & tergesa-gesa. \\
& $\bullet$ G memperkenalkan diri \\
& dan menyapa dengan \\
& malu dan kikuk. \\
\hline
\end{tabular}

\begin{tabular}{lc}
\hline \multicolumn{2}{c}{ Mempertahankan percakapan } \\
\hline VERBAL & VERBAL \\
- G cenderung menjawab & • G menanggapi \\
pertanyaan dengan & pembicaraan orang lain \\
jawaban pendek & dengan jawaban lebih \\
(ya/tidak). & panjang. \\
NONVERBAL & NONVERBAL \\
- G cenderung diam saja & - G memberikan \\
ketika orang lain & pertanyaan lanjutan, \\
berbicara dengannya. & sambil berpikir sekitar 5- \\
& 10 detik. \\
\hline Menutup percakapan & \\
\hline VERBAL & VERBAL \\
- G tidak mengatakan apa- & - G mengundurkan diri, \\
apa untuk menutup & seperti mengatakan “Aku \\
percakapan. & pergi dulu ya”. \\
NONVERBAL & NONVERBAL \\
- G cenderung pergi & $\bullet$ G menutup percakapan \\
meninggalkan orang & sambil melambaikan \\
yang masih berbicara & tangan. \\
dengannya. & \\
\hline
\end{tabular}

Pada komponen Identifying How Others Feel: The Art of Empathy, G dilatih untuk menguasai dua target perilaku, yaitu memahami jenis-jenis emosi beserta situasi yang memunculkan emosi tersebut dan menunjukkan empati. G menunjukkan adanya peningkatkan pada dua keterampilan sosial tersebut. $G$ sudah mampu memahami delapan jenis emosi berdasarkan ekspresi wajahnya, kecuali perasaan bersalah. Sementara itu, G sudah menunjukkan adanya kemajuan dalam menerapkan empati kepada orang lain dengan menyesuaikan ekspresi wajah dengan perasaan orang lain, meskipun belum dapat menunjukkan empatinya melalui bahasa tubuh. Perubahan target perilaku secara rinci dapat dilihat pada Tabel 4.

Tabel 4. Perubahan komponen Identifying How Others Feel: The Art of Empathy

\begin{tabular}{ll}
\hline $\begin{array}{l}\text { Keterampilan sosial } \\
\text { sebelum intervensi }\end{array}$ & $\begin{array}{l}\text { Keterampilan sosial setelah } \\
\text { intervensi }\end{array}$ \\
\hline \multicolumn{1}{c}{ Memahami jenis emosi dan situasi yang memicunya } \\
\hline - G hanya mampu & $\bullet$ G mampu \\
mengidentifikasi 5 emosi & mengidentifikasi 8 \\
dasar (senang, sedih, & ekspresi emosi dengan \\
marah, takut, dan & tepat (senang, sedih, \\
terkejut). & marah, takut, malu, \\
- G melakukan kesalahan & bangga, bosan, jijik, dan \\
dalam menidentifikasi & terkejut). \\
emosi bersalah dan malu & $\bullet$ G sudah mengidentifikasi \\
berdasarkan situasinya. & emosi berdasarkan situasi \\
& yang tepat. \\
\hline \multicolumn{1}{c}{ Menunjukkan empati } & \\
\hline VERBAL & VERBAL \\
- G cenderung & $\bullet$ G menyampaikan bahwa \\
menyampaikan nasihat & ia dapat memahami \\
daripada empati kepada & perasaan orang lain. \\
orang lain. & NONVERBAL \\
NONVERBAL & $\bullet$ G menyesuaikan ekspresi \\
- Ekspresi wajah saat & wajahnya dengan emosi \\
\hline
\end{tabular}




\begin{tabular}{ll}
\hline $\begin{array}{l}\text { memberikan nasihat } \\
\text { cenderung datar. }\end{array}$ & $\begin{array}{l}\text { yang dirasakan orang } \\
\text { lain. }\end{array}$ \\
\hline
\end{tabular}

Berdasarkan pemaparan hasil capaian target perilaku intervensi di atas, $G$ sudah dapat menguasai semua target perilaku yang ada pada komponen keterampilan sosial Creating Positive Interactions dan Identifying How Others Feel: The Art of Empathy. Di sisi lain, G tidak sepenuhnya menguasai komponen keterampilan sosial Getting to Know Others: Starting Conversations. $\mathrm{G}$ menunjukkan peningkatan pada keterampilan mempertahankan dan menutup percakapan, tetapi belum mampu menerapkan keterampilan memulai percakapan.

\section{Hasil intervensi berdasarkan laporan orang tua}

Berdasarkan laporan orang tua menggunakan CBCL, secara umum $G$ menunjukkan penurunan pada masalah menarik diri dan sosial. Terdapat penurunan skor pada aspek withdrawn dan social problem antara pre-test dan post-test 1 . Sebelum intervensi, kedua aspek tersebut berada pada rentang borderline. Setelah intervensi, kedua aspek tersebut turun menjadi rentang normal. Selanjutnya, terdapat penurunan skor pada aspek withdrawn dan social problem antara post-test 1 dan 2 . Pada post-test 2, aspek withdrawn menunjukkan penurunan skor 1 poin, sementara aspek social problem menunjukkan penurunan skor 15 poin. (Lihat Gambar 2).

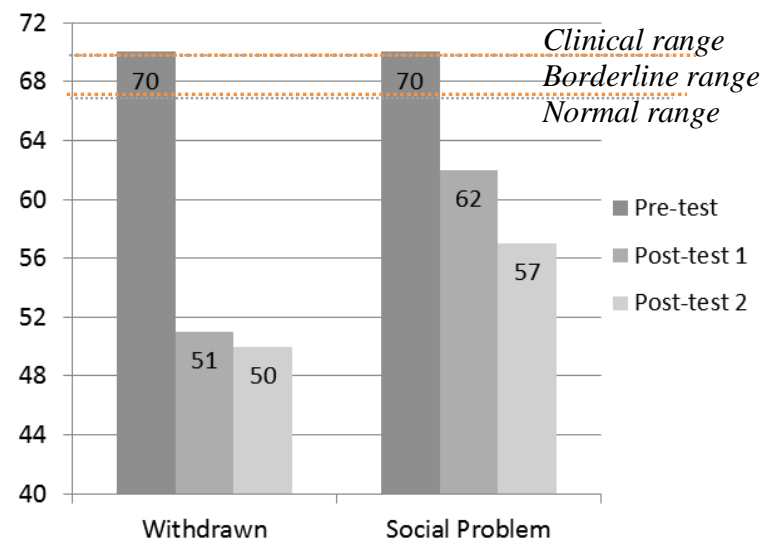

Gambar 2. Hasil withdrawn dan social problem dalam CBCL

Penurunan skor pada aspek withdrawn dan social problem diikuti juga dengan penurunan skor pada internalizing. Baik pada pre-test, post-test 1, dan posttest 2, skor internalizing problem masih tergolong dalam rentang normal. Terdapat penurunan 7 poin antara pretest dengan post-test 1 . Terdapat penurunan skor 5 poin antara post-test 1 dengan post-test 2 (Lihat Gambar 3).

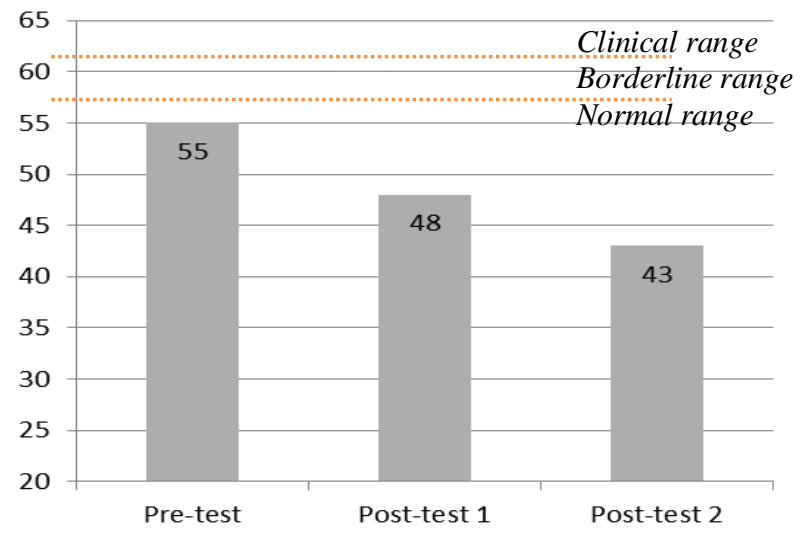

\section{Gambar 3. Perbandingan hasil internalizing problem dalam CBCL}

Berdasarkan pemaparan di atas, hasil laporan dari ibu menunjukkan terdapat penurunan masalah menarik diri, sosial, dan internalizing problem antara sebelum dan sesudah pemberian intervensi. Penurunan skor pada masalah menarik diri, sosial, dan internalizing problem secara konsisten tetap bertahan pada rentang normal setelah intervensi tidak diberikan kembali.

\section{Hasil intervensi berdasarkan laporan guru}

Berdasarkan hasil SSQ, G menunjukkan adanya peningkatan keterampilan sosial antara sebelum dan sesudah intervensi. Terdapat peningkatan skor 15 poin antara pre-test dan post-test 1 serta peningkatan skor 1 poin antara post-test 1 dan post-test 2. Hasil tersebut menunjukkan bahwa terdapat peningkatan keterampilan sosial setelah intervensi dan keterampilan tersebut masih bertahan meskipun intervensi sudah tidak diberikan lagi. Meskipun demikian, keterampilan sosial G masih tergolong di bawah rata-rata keterampilan sosial anak seusianya (Lihat Gambar 4.).

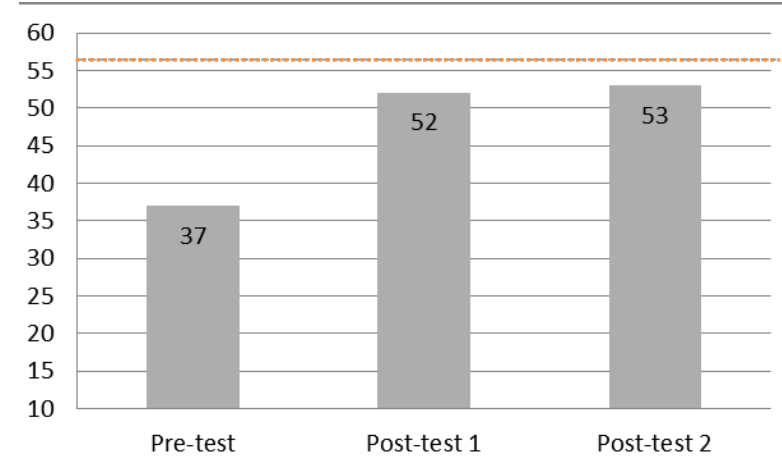

Gambar 4. Perbandingan hasil SSQ*

*Keterangan: Garis putus-putus menunjukkan skor rata-rata anak perempuan usia 8-11 tahun 
Selain berdasarkan SSQ, perubahan keterampilan sosial diukur menggunakan metode wawancara dan observasi. Wawancara dan observasi dilakukan untuk menilai tiga komponen keterampilan sosial yang menjadi indikator keberhasilan intervensi, yaitu memberikan dan menerima pujian, melakukan percakapan, dan menunjukkan empati. Wawancara dan observasi juga digunakan untuk mengetahui perubahan hubungan $\mathrm{G}$ dengan teman sebaya di kelas.

Tabel 5 menunjukkan hasil wawancara dan observasi guru terhadap keterampilan sosial G di sekolah. Secara umum, guru menilai bahwa $G$ menunjukkan peningkatan pada kedua komponen keterampilan sosial, yaitu memberikan dan menerima pujian, serta menunjukkan empati. Namun, pada komponen melakukan percakapan, guru kurang melihat adanya peningkatan. Dalam memulai percakapan, G masih jarang bertanya atau menyapa terlebih dahulu kepada teman. $\mathrm{G}$ cenderung melakukan percakapan dengan teman tertentu saja, tetapi jarang dengan teman yang kurang ia kenal.

Tabel 5. Perubahan Keterampilan Sosial berdasarkan Hasil Wawancara dan Observasi Guru

\begin{tabular}{|c|c|}
\hline $\begin{array}{l}\text { Keterampilan sosial } \\
\text { sebelum intervensi }\end{array}$ & $\begin{array}{l}\text { Keterampilan sosial setelah } \\
\text { intervensi }\end{array}$ \\
\hline \multicolumn{2}{|l|}{ Memberikan pujian } \\
\hline $\begin{array}{l}\text { Hampir tidak pernah terlihat } \\
\text { G memberikan pujian } \\
\text { kepada temannya. }\end{array}$ & $\begin{array}{l}\text { G tampak lebih sering } \\
\text { memberikan pujian } \\
\text { mengenai kemampuan dan } \\
\text { hasil karya orang lain } \\
\text { dengan tersenyum. }\end{array}$ \\
\hline \multicolumn{2}{|l|}{ Menerima Pujian } \\
\hline $\begin{array}{l}\text { G cenderung hanya diam } \\
\text { saja ketika menerima } \\
\text { pujian. }\end{array}$ & $\begin{array}{l}\text { G mengatakan terima kasih } \\
\text { dan membalasnya dengan } \\
\text { pujian. }\end{array}$ \\
\hline \multicolumn{2}{|l|}{ Memulai percakapan } \\
\hline $\begin{array}{l}\text { G jarang sekali memulai } \\
\text { percakapan. Ia hanya } \\
\text { memulai percakapan jika } \\
\text { membutuhkan sesuatu. }\end{array}$ & $\begin{array}{l}\text { G masih jarang memulai } \\
\text { percakapan. Ia tampak ragu- } \\
\text { ragu dan kaku untuk } \\
\text { memulai percakapan. }\end{array}$ \\
\hline \multicolumn{2}{|c|}{ Mempertahankan percakapan } \\
\hline $\begin{array}{l}\text { Ketika teman mengajak } \\
\text { berbicara, } G \text { cenderung } \\
\text { tidak merespons atau hanya } \\
\text { memberikan jawaban } \\
\text { pendek. }\end{array}$ & $\begin{array}{l}\text { G dapat bertanya kembali } \\
\text { jika ada teman yang } \\
\text { mengajaknya berbicara. }\end{array}$ \\
\hline \multicolumn{2}{|l|}{ Menutup percakapan } \\
\hline $\begin{array}{l}\text { Percakapan ditutup ketika } \\
\text { G hanya diam saja tanpa } \\
\text { memberikan tanggapan } \\
\text { apapun. }\end{array}$ & $\begin{array}{l}\text { G berpamitan setelah ia } \\
\text { selesai berbicara dengan } \\
\text { orang lain. }\end{array}$ \\
\hline \multicolumn{2}{|l|}{ Menunjukkan empati } \\
\hline $\begin{array}{l}\text { G kurang mampu } \\
\text { menyesuaikan emosinya } \\
\text { dengan emosi lawan bicara. } \\
\text { Ketika teman sedang } \\
\text { membicarakan sesuatu hal } \\
\text { yang menyenangkan, } \\
\text { ekspresi emosi G cenderung }\end{array}$ & $\begin{array}{l}\text { G dapat mendengarkan } \\
\text { cerita teman yang sedang } \\
\text { bersedih. G biasanya } \\
\text { menunjukkan empatinya } \\
\text { dengan dukungan atau } \\
\text { bantuan pada teman yang } \\
\text { sedang kesulitan. } \\
\end{array}$ \\
\hline
\end{tabular}

datar.

Berkaitan dengan hubungan $G$ dengan temantemannya di kelas, guru melaporkan bahwa $G$ masih menjalin pertemanan dengan teman tertentu saja, khususnya teman yang duduk di dekatnya atau yang selalu bersama-sama dalam satu kelompok tugas. Hubungan dengan teman-teman tersebut menunjukkan adanya kedekatan yang lebih positif. Meskipun demikian, $\mathrm{G}$ masih kesulitan dalam menjalin pertemanan dengan orang yang belum ia kenal sama sekali.

Berdasarkan laporan yang diberikan guru, dapat disimpulkan bahwa $\mathrm{G}$ menunjukkan adanya peningkatan keterampilan sosial berdasarkan hasil SSQ. Peningkatan tersebut tetap bertahan sesudah intervensi tidak diberikan kembali. Hasil wawancara dan observasi juga menunjukkan adanya peningkatan terhadap keterampilan memberikan dan menerima pujian serta menunjukkan empati, meskipun tidak disertai dengan peningkatan pada keterampilan memulai percakapan. Peningkatan keterampilan sosial $\mathrm{G}$ juga menunjukkan dampak yang positif terhadap kedekatan $G$ dengan teman-teman di kelasnya.

Berdasarkan uraian hasil analisis di atas, intervensi SST yang diberikan kepada $G$ terbukti berhasil dalam meningkatkan beberapa keterampilan sosial G, terutama keterampilan dalam memberikan dan menerima pujian, mempertahankan dan menutup percakapan, dan menunjukkan empati. Peningkatan keterampilan sosial tersebut sejalan dengan kemampuan $G$ untuk menjalin hubungan yang lebih dekat dengan teman sebaya menurut laporan dari orang tua dan guru.

Keberhasilan intervensi ini sejalan dengan pendapat LeCroy (2008) bahwa SST merupakan metode penanganan yang bertujuan untuk mengajarkan keterampilan yang dibutuhkan dalam mempertahankan interaksi sosial. Keberhasilan SST dalam penelitian ini sejalan dengan beberapa penelitian yang sudah dilakukan sebelumnya (LeCroy \& Mann, 2004; Sukhodolsky et al., 2005). Penelitian yang dilakukan oleh Van Vugt, Deković, Prinzie, Stams, \& Asscher (2013) menunjukkan bahwa SST secara signifikan berhasil meningkatkan perubahan positif pada masalah internalizing dan sosial pada anak usia sekolah. Lebih lanjut, efek SST yang diuji 12 bulan kemudian menunjukkan bahwa peningkatan tersebut masih tetap bertahan. Selanjutnya, Schneider (1992) melaporkan bahwa SST paling efektif diberikan kepada anak dengan masalah menarik diri karena menunjukkan effect size yang paling tinggi dibandingkan anak dengan masalah agresi atau anak yang kurang populer. Oleh karena itu, SST dinilai memberikan efek yang positif bagi $G$ yang juga memiliki masalah menarik diri dalam lingkungan sosial yang baru.

SST dinilai tidak hanya berpengaruh terhadap keterampilan sosial, tetapi juga berpengaruh terhadap kemampuan menjalin hubungan pertemanan. Setelah 
mengikuti SST, G telah berhasil membangun hubungan yang lebih baik dengan teman-temannya di sekolah dengan cara menerapkan keterampilan sosial yang sudah ia pelajari. Spence (2003) menjelaskan bahwa seseorang membutuhkan keterampilan sosial untuk dapat berhasil menjalin interaksi dengan orang lain. Seseorang dapat mencapai kompetensi sosial ketika ia dapat menerapkan berbagai keterampilan sosial dalam berinteraksi dengan teman sebaya sehari-hari. Ketika $G$ berlatih untuk menerapkan keterampilan sosial di sekolah, ia juga berlatih untuk berinteraksi lebih baik dengan teman sebaya. Hal tersebut didukung dengan hasil pengukuran orang tua yang menunjukkan adanya penurunan pada masalah menarik diri dan sosial. Di samping itu, guru juga melaporkan bahwa $G$ sudah mampu menjalin hubungan yang lebih positif dengan beberapa teman sebaya di sekolah.

Tidak semua target perilaku dalam intervensi ini sudah dapat dicapai oleh G. Pada komponen melakukan percakapan, $G$ hanya mampu menguasai kemampuan mempertahankan dan menutup percakapan, sementara dalam memulai percakapan, ia masih kesulitan. Spence (2003) menjelaskan bahwa dalam memulai percakapan, terdapat keterampilan sosial tingkat mikro, seperti mengidentifikasi situasi yang tepat untuk memulai percakapan dan memilih topik percakapan dengan tepat. $\mathrm{G}$ diduga belum mampu menguasai kemampuan memulai percakapan karena ia tidak tahu situasi yang tepat dalam memulai percakapan dengan teman sebaya dan topik apa yang sesuai dengan situasi sosial itu.

Terdapat tiga faktor yang menunjang efektivitas dari intervensi ini. Pertama, motivasi $G$ untuk mengikuti proses intervensi yang terlihat dari sikap kooperatif yang ditunjukkan selama mengerjakan latihan, mengikuti roleplay, dan menyelesaikan tugas rumah yang diberikan. Hal tersebut ditunjang oleh penggunaan token economy sebagai reinforcement. Eisler dan Frederiksen (1980) menjelaskan bahwa positive reinforcement biasa diberikan kepada klien ketika mereka dapat menampilkan perilaku yang diinginkan selama pelatihan atau dalam situasi sehari-hari. Dengan reinforcement ini, motivasi klien akan meningkat untuk menerapkan performa sosial tertentu dan mempertahankannya.

Kedua, hal yang mendukung efektivitas SST adalah keterlibatan ibu selama proses intervensi. Middleton \& Cartledge (1995) menjelaskan mengenai pentingnya peran orang tua dalam pelaksanaan SST kepada anak. Ketika orang tua dilibatkan untuk mendorong anak dalam menerapkan keterampilan di luar sesi intervensi dan memahami setiap sesi intervensi dan tugas rumah anak, SST yang diterapkan cenderung lebih berhasil daripada SST tanpa melibatkan peran orang tua (Middleton \& Cartledge, 1995). Dalam penelitian ini, ibu saja yang banyak terlibat, sedangkan ayah tidak terlibat sama sekali karena kesibukan dalam pekerjaan. Selama sesi, peneliti menjelaskan kepada ibu mengenai materi yang diajarkan, kemampuan yang sudah dicapai $\mathrm{G}$, meminta ibu untuk melatih keterampilan tersebut di rumah, dan mengingatkan tentang tugas rumah yang harus dikerjakan. Keterlibatan ibu tersebut membantu $G$ untuk meningkatkan dan mempertahankan keterampilan sosialnya di luar sesi intervensi.

Ketiga, jenis teknik yang digunakan dalam melatih keterampilan sosial $\mathrm{G}$ dengan menggunakan pendekatan perilaku (behavioral social skill training) berupa teknik modeling, behavior rehearsal, seperti roleplay, feedback, dan reinforcement (Spence, 2003). Eisler \& Frederiksen (1980) memaparkan bahwa berdasarkan beberapa penelitian, teknik modeling memberikan kontribusi penting dalam proses mencapai keterampilan yang diinginkan. Modeling membantu anak untuk memahami bagaimana menerapkan perilaku yang kompleks. Selanjutnya, behavior rehearsal, seperti roleplay terbukti efektif dalam membantu trainer untuk mengamati keterampilan partisipan dan memberikan saran untuk meningkatkan keterampilan tersebut. Dengan teknik-teknik tersebut, $G$ berhasil mempelajari target perilaku yang diharapkan dalam intervensi ini.

Terdapat beberapa limitasi yang terjadi dalam proses penelitian ini. Limitasi yang pertama adalah setting pelaksanaan intervensi yang terbatas hanya di kampus, bukan pada situasi sehari-hari seperti di rumah dan di sekolah G. Finch \& Hops (1983) memaparkan bahwa sekolah merupakan setting yang tepat untuk melaksanakan SST karena memberikan kesempatan pada anak untuk berlatih keterampilan sosial dengan teman sebaya. Pada pelaksanaan intervensi ini, setting intervensi yang terbatas hanya di kampus, berpengaruh pada kesempatan $G$ untuk berlatih secara langsung pada setting interaksi sosial sehari-hari dalam menerapkan keterampilan sosial, terutama dalam memulai percakapan.

Limitasi kedua adalah minimnya keterlibatan teman sebaya selama sesi intervensi. Eisler \& Frederiksen (1980) menjelaskan bahwa intervensi yang melibatkan latihan dengan teman sebaya dinilai lebih efektif dalam membentuk keterampilan sosial dibandingkan hanya melibatkan trainer ketika modeling atau melakukan roleplay. Sejalan dengan hal tersebut, Finch \& Hops (1983) menjelaskan bahwa intervensi yang diberikan dengan minim atau tidak ada kesempatan untuk interaksi sosial dengan teman sebaya cenderung tidak dapat digeneralisasikan pada situasi sosial yang lain. G cenderung lebih banyak berlatih dengan peneliti pada saat mengajarkan tentang keterampilan dalam memulai dan mempertahankan percakapan. Minimnya keterlibatan teman sebaya dan lebih banyak berlatih dengan peneliti menyebabkan $\mathrm{G}$ kurang mampu menguasai keterampilan yang diajarkan.

\section{SIMPULAN}

Program Social Skill Training kepada G menunjukkan hasil yang positif dalam meningkatkan keterampilan sosial G. Efektivitas program ini tampak melalui laporan dari orang tua dan guru. Berdasarkan 
laporan dari orang tua, terdapat penurunan skor pada aspek withdrawal dan social problem yang sebelumnya berada pada rentang borderline menjadi rentang normal. Lebih lanjut, ada pula penurunan pada skor internalizing problem. Berdasarkan pengukuran yang dilakukan oleh guru, $\mathrm{G}$ menunjukkan peningkatan keterampilan sosial meskipun skor tersebut masih berada di bawah rata-rata anak seusianya. Berdasarkan hasil wawancara dan observasi yang dilakukan oleh guru, komponen keterampilan sosial dalam menerima dan memberikan pujian serta menunjukkan empati sudah meningkat. Akan tetapi, pada komponen melakukan percakapan, terutama memulai percakapan, kurang terdapat adanya peningkatan setelah intervensi diberikan. Peningkatan keterampilan sosial pada $G$ ini sejalan dengan peningkatan hubungan pertemanan di sekolah.

Penelitian selanjutnya dapat mengembangkan intervensi SST dengan melibatkan teman sebaya pada setting sehari-hari anak, seperti sekolah. Di samping itu, pengukuran keterampilan sosial sebaiknya dapat melibatkan teman sebaya yang dianggap paling memahami perilaku dari partisipan penelitian sehingga menghasilkan pengukuran yang lebih valid dan reliabel.

\section{UCAPAN TERIMA KASIH}

Ucapan terima kasih diberikan kepada orang tua, guru, dan teman partisipan yang telah bersedia untuk bekerja sama dan mendukung program intervensi ini hingga dapat berhasil meningkatkan keterampilan sosial partisipan.

\section{DAFTAR PUSTAKA}

Achenbach, T. M. (1991). Child Behavior Checklist/418 . Retrieved from https://www.unc.edu/depts/sph/ longscan/pages/measures/Age16/writeups/Age $\% 2$ 016\%20Child\%20Behavior\%20Checklist\%20EX TERNAL\%20\%20SITE\%20MM\%20FINAL.pdf

Bagwel, C. L. (2005). Friendship, peer network, and antisocial behavior. In Kupersmidt, J. B., Dodge, K. A (Eds.). Children's peer relation: From development to intervention. Washington DC: American Psychological Association

Berk, L. E. (2013). Child development (9th ed.). Upper Saddle River, NJ: Pearson Education.

Blundon, J. A., \& Schaefer, C. E. (2006). The use of group play therapy for children with social skills deficits. In H. G. Kaduson \& C. E. Schaefer (Eds.). Short-term play therapy for children $\left(2^{\text {nd }}\right.$ ed.) (pp. 336-375). New York, NY: Guilford Press.

Buhs, E. S., \& Ladd, G. W. (2001). Peer rejection as antecedent of young childrens school adjustment: An examination of mediating processes. Developmental Psychology, 37(4), 550-560. doi: 10.1037//00121649.37.4.550
Bukowksi, W.M., Motzoi, C., \& Meyer, F. (2009). Friendship as process, function, and outcome. In K.H. Rubin, W.M. Bukowski, \& B. Laursen (Eds.). Handbook of peer interaction, relationship, and groups (pp. 217-231). New York: Guilford Press.

Bulkeley, R., \& Cramer, D. (1994). Social skills training with young adolescents: group and individual approaches in a school setting. Journal of Adolescence, 17(6), 521-531. doi: 10.1006/jado.1994.1046

Chen, X., Rubin, K. H., \& Li, D. (1997). Relation between academic achievement and social adjustment: Evidence from Chinese children. Developmental Psychology,33(3), 518525. doi: 10.1037/0012-1649.33.3.518

Eisler, R. M., \& Frederiksen, L. W. (1980). Perfecting social skills: A guide to interpersonal behavior development. New York, NY: Plenum Press

Fandrem, H. (2015). Friendship during adolescence and cultural variations. International Encyclopedia of the Social \& Behavioral Sciences, 432-441. doi: 10.1016/b978-0-08-097086-8.23192-9

Finch, M., \& Hops, H. (1983). Remediation of social withdrawal in young children: considerations for the practitioner. In C. W. LeCroy (Ed.). Social skills training for children and youth (pp. 29-42). New York, NY: The Haworth Press

Gravetter, F. J. \& Forzano, L. B. (2012). Research Methods for the Behavioral Sciences, 4th edition. California: Wadsworth.

Gruenenfelder-Steiger, A. E., Harris, M. A., \& Fend, H. A. (2016). Subjective and objective peer approval evaluations and self-esteem development: A test of reciprocal, prospective, and long-term effects. Developmental Psychology, 52(10), 15631577. doi: $10.1037 / \mathrm{dev} 0000147$

Gustavsen, A. M. (2017). Longitudinal relationship between social skills and academic achievement in a gender perspective. Cogent Education, 4(1). doi: 10.1080/2331186x.2017.1411035

Hazel, J. S., Schumaker, J. B., Sherman, J. A., \& Sheldon-Wildgen, J. (1983). Social skills training with court-adjudicated youths. In C. W. LeCroy (Ed.). Social skills training for children and youth (pp.117-138). New York, NY: The Haworth Press

Hupp, S. D. A., LeBlanc, M., Jewell, J. D., \& Warnes, E. (2009). History and overview. In J. L. Matson. Social behavior and skills in children (pp. 1-21). New York, NY: Springer

Konold, T. R., Jamison, K. R., Stanton-Chapman, T. L., \& Rimm-Kaufman, S. E. (2010). Relationships among informant based measures of social skills and student achievement: A longitudinal examination of differential effects by sex. Applied Developmental Science, 14(1), 18-34. doi: 10.1080/10888690903510307

LeCroy, C. W. (1983a). Promoting social competence in early adolescents: An experimental investigation. 
LeCroy, C. W. (1983b). Social skills training with adolescents: A review. In C. W. LeCroy (Ed.). Social skills training for children and youth (pp. 91-116). New York, NY: The Haworth Press

LeCroy, C. W. (2008). Social skill training: A treatment manual. In C. W. LeCroy (Ed.). Handbook of evidence-based treatment manuals for children and adolescents (2nd ed., pp. 99-136). New York, NY: Oxford University Press

LeCroy, C. W. (2013). Designing and facilitating groups with children. In C. Franklin, M. B. Harris, \& P. Allen-Meares (Eds.). The school services sourcebook: A guide for school-based professionals (2nd ed., pp. 611 -618). Greenwich, CT: JAI Press .

LeCroy, C. W. (2015). Case study 2-1: A social skills group for children. In C. W. LeCroy \& E. K. Anthony. Case Studies in Child, Adolescent, and Family Treatment (pp. 133-144) New Jersey: John Wiley \& Sons

LeCroy, C. W., \& Mann, J. (2004). Preventing substance abuse among youth: Universal, selected and targeted interventions. In L. A. Rapp-Paglicci, C. N. Dulmus, \& J. S. Wodarski (Eds.), Handbook of preventive interventions for children and adolescents (pp. 198-226). Hobokin, NJ: John Wiley.

LeCroy, C. W., \& Rose, S. D. (1986). Evaluation of preventive interventions for enhancing social competence in adolescents. Social Work Research and Abstracts, 22, 8-17

Malikiosi-Loizos, M., \& Anderson, L. R. (1999). Accessible friendships, inclusive friendships, reciprocated friendships as related to social and emotional loneliness in Greece and the USA. European Psychologist, 4(3), 165-178. doi: 10.1027//1016-9040.4.3.165

Michelson, L., Sugai, D. P., Wood, R. P., \& Kazdin. A. E. (1983). Social skills assessment and training with children: An empirically based handbook. New York: Plenum Press

Middleton, B., \& Cartledge, G. (1995). The effects of social skill instruction and parental involvement on the aggressive behaviors of African American males. Behavior Modification, 19(2), 192-210

Prinstein, M.J., Rancourt, D., Guerry, J.D., \& Browne, C.B. (2009). Peer reputations and psychological adjustment. In K.H. Rubin, W.M. Bukowski, \& B. Laursen (Eds.). Handbook of peer interaction, relationship, and groups (pp. 548-567). New York: Guilford Press.

Rose, S. R. (1983). Promoting social competence in children: A classroom approach to social and cognitive skill training. In C. W. LeCroy. Social skills training for children and youth (pp. 43-60). New York, NY: The Haworth Press

Rubin, K. H., Coplan, R., Chen, X., Bowker, J., McDonald, K. L. (2011). Peer relationship in childhood. In M. E. Lamb \& M. H. Bornstein (Eds.). Social and personality development: An advanced textbook (pp. 309-3360). New York: Psychology Press

Schneider, B. H. (1992). Didactic methods for enhancing children's peer relations: A quantitative review. Clinical Psychology Review, 12(3), 363-382.

Segrin, C. (2000). Social skills deficits associated with depression. Clinical Psychology Review, 20(3), 379403. doi: 10.1016/s0272-7358(98)00104-4

Shaffer, D. R. (2009). Social and personality development (6th ed.). Belmont, CA: Wadsworth Cengage Learning

Spence, S.H. (1995). Social skill training: Enhancing social competence with children and adolescent. Windsor, UK: The NFER-NELSON Publishing Company, Ltd.

Spence, S. H. (2003). Social skills training with children and young people: Theory, evidence and practice. Child and Adolescent Mental Health, 8(2), 84-96

Sukhodolsky, D. G., Golub, A., Stone, E. C., \& Orban, L. (2005). Dismantling anger control training for children: A randomized pilot study of social problem-solving versus social skills training components. Behavior Therapy, 36(1), 15-23.

Troop-Gordon, W., Macdonald, A. P., \& Corbitt-Hall, D. J. (2019). Children's peer beliefs, friendlessness, and friendship quality: Reciprocal influences and contributions to internalizing symptoms. Developmental Psychology. doi: 10.1037/dev0000812

Van Vugt, E. S., Deković, M., Prinzie, P., Stams, G. J. J. M., \& Asscher, J. J. (2013). Evaluation of a groupbased social skills training for children with problem behavior. Children and Youth Services Review, 35(1), 162-167.

Whitted, K. S. (2011). Understanding How Social and Emotional Skill Deficits Contribute to School Failure. Preventing School Failure: Alternative Education for Children and Youth, 55(1), 10-16. doi: 10.1080/1045988090328675 